\title{
Os amrides: a florescente dinastia escondida de Israel
}

\author{
Orientadora: Prof ${ }^{a}$. Maria de Lourdes Corrêa Lima
}

Pesquisador: Michel Alves dos Santos

\author{
Fonte: $\mathrm{CNPq}$
}

\section{Introdução}

Segundo as tradições bíblicas, após a morte de Salomão (970-931), assume o governo do Reino unido de Judá e Israel, Roboão (931-913). Este jovem rei, desprezando os conselhos dos anciãos (1 Rs 12,6-8) de Jerusalém, impõe um duro regime tributário às tribos do Norte. Estas, sob a liderança de Jeroboão (931-910), diante da postura irredutível de Roboão, declaram-se independentes do governo de Jerusalém (1 Rs 12,16). A partir de então, a antiga monarquia unida divide-se em dois reinos: o Reino de Judá, ao sul, governado por Roboão, e o Reino de Israel, ao norte, liderado por Jeroboão.

O Reino do Sul, seguindo a profecia de Samuel (2 Sm 7,11-16), manteve uma estabilidade dinástica. Seu trono, até a queda de Jerusalém (587), foi sempre ocupado por alguém da casa de Davi. O Reino do Norte, por sua vez, sempre enfrentou problemas para estabelecer uma dinastia. Esta situação de Israel alcançou tamanha gravidade que, em menos de cinqüenta anos de existência, subiram ao trono seis reis pertencentes a quatro dinastias diferentes.

Amri (884-873) é o primeiro monarca do Reino do Norte a estabelecer uma dinastia que durasse mais do que duas gerações. A casa de Amri governou Israel por quarenta e quatro anos. Os amrides ocuparam o trono do Norte durante quatro gerações. De acordo com o testemunho bíblico, Amri foi o responsável pela fundação de Samaria (1 Rs 16,24), capital de Israel. Este rei foi sucedido por Acab (873-852), que se casou com a princesa fenícia Jezabel (1 Rs 16,31), construiu um templo para Baal na Samaria (1 Rs 16,32), confrontou-se com o profeta Elias, adquiriu as vinhas de Nabot (1 Rs 21,8-16) e guerreou contra os arameus. Após a morte deste rei, no campo de batalha de Ramot Galaad (1 Rs 22,29-38), sobe ao trono de Israel seu filho Ocozias 
(852-851), que logo adoece e morre. Ele é sucedido por Jorão (851-842). Este rei derrota Moab (2 Rs 3,9), é ferido na Batalha contra Hazael (2 Rs 8,28), rei de Damasco, e é morto por Jeú (2 Rs 9,24), um de seus comandantes, em uma revolta orquestrada pelo profeta Eliseu (2 Rs 9,1-3.6).

Os amrides ficaram conhecidos na história pela sua obstinação idolátrica e "ficaram quase totalmente obscurecidos em virtude da condenação da Bíblia” (1). Entretanto, nesta época ocorreram diversas obras monumentais e relevantes acontecimentos internos no Reino de Israel e em suas relações com os reinos vizinhos. As evidências extra-bíblicas e os achados arqueológicos, ocorridos no século XX da era cristã, em Samaria, Meguido, Dan e Hasor, lançaram novas luzes a este momento histórico. Isto oferece uma nova oportunidade de se fazer uma reconstrução e uma releitura da história do antigo Israel, buscando uma nova interpretação dos fatos e dos textos bíblicos.

\section{Objetivos}

A presente pesquisa buscou compreender melhor a visão tradicional acerca dos fatos relatados no texto bíblico sobre os amrides. O estudo também procurou entender o projeto teológico que se esconde por detrás da imagem negativa criada acerca da dinastia de Amri. A pesquisa ainda procurou, de alguma forma, entender, com base nas descobertas arqueológicas, como se deu o governo da mencionada dinastia e refletir e tirar conclusões acerca deste período da história do antigo Israel e da perspectiva adotada pelos autores dos textos bíblicos que se referem a esta época. 